$\xi=1$

\title{
Impact of various cooking methods on the micronutrient compositions of selected legumes in Eastern Nigeria
}

\author{
Agomuo Emmanuel Nnabugwu ${ }^{1}, *$ Amadi Peter Uchenna ${ }^{2}$, \\ Iheka Chidiebere Uchenna ${ }^{2}$, Duru Majesty Kelechukwu ${ }^{3}$ \\ ${ }^{1}$ Department of Biochemistry, Imo State University, Owerri, Imo State \\ ${ }^{2}$ Department of Biochemistry, University of Port Harcourt, Choba, Rivers State \\ ${ }^{3}$ Department of Chemical Sciences (Biochemistry Unit), Rhema University, Aba, Abia State \\ *Corresponding author E-mail: peter_amadi@uniport.edu.ng
}

\begin{abstract}
The impact of various methods of cooking on the concentration of some micronutrients in African Breadfruit (Treculia africana), Melon seeds (Citrullus vulgaris), Groundnut (Arachis hypogea), African oil bean (Pentaclethra macrophylla), Cashew nut (Anacardium occidentale) and Coconut (Cocos nucifera) samples were evaluated using standard methods. The results show that only the $\beta$-carotene and potassium contents of African Breadfruit were significantly affected by the various forms of heat processing applied. A significant $(\mathrm{p}<0.05)$ increase in the $\beta$-carotene content was observed for the melon seeds samples on application of heat by boiling $(19223.61 \pm 4.00 \mathrm{mg} / 100 \mathrm{~g})$ and microwave cooking $(19028.59 \pm 62.12 \mathrm{mg} / 100 \mathrm{~g})$, compared to the raw samples $(12462.13 \pm 39.11 \mathrm{mg} / 100 \mathrm{~g})$, which was equally observed for, groundnut, and cashew nut samples. Heat processing by boiling, pressure cooking, and microwave cooking significantly reduced the $\mathrm{K}$ content of the melon seeds, while heat processing by frying caused no significant effect. The $\mathrm{Mg}$, $\mathrm{Mn}, \mathrm{Na}, \mathrm{Zn}$, and $\mathrm{Ca}$ contents of the melon seeds were unaffected by the forms of heat applied. For the oil bean samples, the total carotenoid, $\mathrm{K}, \mathrm{Na}$, and $\mathrm{Ca}$ contents showed a significant decrease on application of the processing methods used in this study, while a similar result was obtained for the heat processed coconut samples, with an additional change in the $\mathrm{Mg}$ content, on application of heat. This study has shown that, Boiling, Frying, Pressure cooking and Microwave cooking affected the micronutrient composition of the selected legumes. Cooking by boiling showed the most retention of the micronutrients whereas the frying and microwave cooking methods showed more losses in micronutrient content.
\end{abstract}

Keywords: Micronutrient; Frying, Boiling, Microwave Cooking; Pressure Cooking; Carotene; Breadfruit.

\section{Introduction}

Quality nutrition is a fundamental human right. The relationship that exists between food, nutrition and health should be buttressed so as to have a healthy environment that can promote development. In order to achieve this, developing countries exploit conventional local resources so as to satisfy the needs of the increasing population (Hegsted et al., 1976). Exposure of humans to toxic elements occurs through several routes that include consumption of contaminated foods and water and inhalation of air pollutants therefore it is vital to monitor foods for contamination. For nonoccupationally exposed individuals, the most likely source of trace elements ingestion is the diet (USEPA, 1987). The mineral elements are distinct from other vital nutrients like carbohydrates, proteins, fats and vitamins (Hegsted et al., 1976). In this era, biological analytical methods made clear the importance and significance of mineral elements for human and animal nutrition and modern assay techniques led to the discovery of trace elements as essential nutrients. This is still an active area of current research. Minerals are critical in the regulation of several functions which include: red blood synthesis, permeability, muscles contraction, blood clotting, heart function, protein synthesis and the regulation of a number of cell membrane (Hendricks, 2002; Aremu et al., 2005). For examples, magnesium activates many enzyme systems also maintaining the electrical potential in nerves (Shils, 1973).
Calcium in association with vitamins A, C and D, protein, phosphorous, manganese, protein and magnesium, are all involved in bone formation (Fleck, 1976). Calcium is also important in certain enzymes metabolic processes, muscle contraction and blood clotting (Aremu et al., 2005). Phosphorous helps calcium in diverse body reactions although having independent function (Fleck, 1976). Sodium and potassium are required to maintain osmotic balance of the body fluids, control glucose absorption, nerve irritability, muscle regulation and $\mathrm{pH}$ of body fluids (Pike and Brown, 1967; Shils, 1973). Zinc is present in all tissues of the body and it is a component of more than fifty enzymes. Iron has been reported to be very pertinent for normal functioning of the central nervous system (Vyas and Changra, 1984). Iron also facilitates the oxidation of carbohydrates, proteins and fats (Aremu et al., 2005).

Cooking is an essential process that not only makes foods edible but also enables maximum utilization of the components present in the food for the maintenance of the body (Kala and Prakash, 2001). Cooking is responsible for losses of vitamins and minerals in foods. However, the bioavailability of some minerals, for example iron, may be increased by cooking (Lee and Clydesdale, 1981). Losses of vitamins and minerals during processing and cooking can occur either due to oxidation or by dissolving in water (Tapadia, 1995). Nutrients may also be destroyed when foods are processed because of their sensitivity to heat, light, oxygen, 
$\mathrm{pH}$ of the solvent or a combination of these (Harris, 1988). Loss of nutrients may also occur between harvesting and distribution, during household and industrial handling as well as catering and during storage (Somogyi, 1990).

The effect of cooking losses on vitamin and mineral intake is an important consideration in dietary and epidemiological studies in several countries. Many studies have focused on the chemical properties and nutrient composition of these selected legumes. However, there is a dearth of information on how the application of heat affects the major and trace metals composition of these well consumed foods. The aim of the present investigation was to ascertain the impact of various methods of cooking (Boiling, Frying, Pressure cooking and Microwave cooking) on the levels of ten major and trace elements $\{\beta$-carotene, Ascorbic acid, Copper $(\mathrm{Cu})$, Iron $(\mathrm{Fe})$, Potassium $(\mathrm{K})$, Magnesium $(\mathrm{Mg})$, Manganese $(\mathrm{Mn})$, Sodium $(\mathrm{Na})$, Zinc $(\mathrm{Zn})$ and Calcium $(\mathrm{Ca})\}$ in African Breadfruit (Treculia africana), Melon seeds (Citrullus vulgaris), Groundnut (Arachis hypogea), African oil bean (Pentaclethra macrophylla), Cashewnut (Anacardum occidentalia) and Coconut (Cocos nucifera).

\section{Materials and methods}

\subsection{Collection and preparation of sample}

The selected legume seeds were all purchased at Ekeonuwa market, at Owerri, Imo State, Nigeria. The samples were cleaned and extraneous materials like dirt and stones were removed and then they were divided into five portions. The first part was ground raw and was uncooked which served as the control; the second part was boiled; the third part was fried; the fourth part was pressure cooked whereas the fifth part was microwave cooked.

\subsection{Sample processing}

- The uncooked samples were analyzed without prior treatment.

- For boiling, the raw samples were blanched in a $250 \mathrm{~mL}$ conical flask at $100^{\circ} \mathrm{C}$ for $10 \mathrm{~min}$, drained through a plastic sieve. The samples were then boiled until they were soft and ready for consumption. The samples were sifted and allowed to dry at room temperature. No other ingredients were added. Samples were allowed to cool and afterwards packed in new sealable polyethylene bags ready for laboratory analysis.

- For frying, the raw samples were blanched in a $250 \mathrm{~mL}$ conical flask at $100^{\circ} \mathrm{C}$ for $10 \mathrm{~min}$, drained through a plastic sieve. The samples were fried by heating in an oven at a temperature of $105^{\circ} \mathrm{C}$ until it turned brown and was ready for consumption as processed by local vendors. Samples were packed in new sealable polyethylene bags ready for laboratory analysis.

- For pressure cooking, the raw samples were blanched in a $250 \mathrm{~mL}$ conical flask at $100^{\circ} \mathrm{C}$ for $10 \mathrm{~min}$, drained through a plastic sieve. The samples were then pressure cooked until they were soft and ready for consumption. The samples were sifted and allowed to dry at room temperature. No other ingredients were added. Samples were allowed to cool and afterwards packed in new sealable polyethylene bags ready for laboratory analysis.

- For microwave cooking, the raw samples were initially blanched as indicated above, drained through a plastic sieve. The samples were then microwave cooked until they were soft and ready for consumption. The samples were sifted and allowed to dry at room temperature. No other ingredients were added. Samples were allowed to cool and afterwards packed in new sealable polyethylene bags ready for laboratory analysis.

\subsection{Analysis of samples}

As described by Nnorom et al. (2015), preparation of the samples as described above was succeeded by analysis without further pretreatment. The legume samples were crushed in porcelain mortar, homogenized and then dried to constant weight. One gram was ashed in a muffle furnance at a temperature of $450{ }^{\circ} \mathrm{C}$ for $5 \mathrm{~h}$ and the ash transferred quantitatively into a $250 \mathrm{~mL}$ conical flask and thereafter digested with $10 \mathrm{~mL}$ of the digestion acid mixture (ratio 1:2:2 of perchloric, nitric and sulphuric acids) with heating on a hot plate in a fume hood until evolution of white fumes. The digest was allowed to cool and $20 \mathrm{~mL}$ of distilled water was added to bring the metals into solution; and then filtered using ashless Whatman filter paper into a $100 \mathrm{~mL}$ calibrated volumetric flask and made up to mark with distilled water. The digests were subsequently analyzed for $\mathrm{Cu}, \mathrm{Fe}, \mathrm{K}, \mathrm{Mg}, \mathrm{Mn}, \mathrm{Na}, \mathrm{Zn}$ and $\mathrm{Ca}$ using Phoenix 986 (Biotech Engineering Management Co. Ltd. UK) flame atomic absorption spectrophotometer. Provitamin A ( $\beta$ carotene) content was determined by the method adopted by IVACG, (1992). UV absorption measurement of the samples was made at $328 \mathrm{~nm}$ after extraction with chloroform. Calibration curve of the spectrophotometric measurement of $\beta$-carotene standard solutions was also made at $328 \mathrm{~nm} ; \beta$-carotene estimation of the sample was made from this.

Vitamin $A=\frac{\text { Absorbance of sample } \times \text { Dilution factor }}{\text { Weight of sample }}$

Ascorbic acid (Vitamin C) was estimated by 2, 6- dichlorophenol indophenols method (Jones and Hughes, 1983)

Samples were generally handled carefully to avoid contamination. All chemicals used were of analytical grade. To eliminate the risk of contamination during the experiments, all plastic and glassware were carefully cleaned by washing, rinsing severally with tap water, and then soaking in $5 \% \mathrm{HNO}_{3}$ solution for a minimum of $24 \mathrm{~h}$. They were rinsed severally with deionised water before use.

\subsection{Statistical analysis of data}

The data for were analyzed for statistical differences by means of one-way ANOVA and post hoc LSD, on SPSS 19. In all $p$ value of less than $0.05(\mathrm{p} \leq 0.05)$ was considered to be significant. Data are presented as mean \pm SD (standard deviation).

\section{Results and discussion}

ß-carotene content of the Uncooked African bread fruit $(12278.94 \pm 18.60)$ was significantly lower when compared to the other cooking methods; the Boiled (18817.08 \pm 5.06$)$, Fried (18923.11 \pm 4.60$)$, Pressure cooking $(18355.83 \pm 96.43)$ and Microwave cooking (18265.33 \pm 17.34$)$. Decrease was in this order: Uncooked $<$ Microwave cooking $<$ Pressure cooking $<$ Boiled $<$ Fried indicating that by application of heat, the beta carotene content increased. There was no significant difference in Ascorbic acid, $\mathrm{Cu}, \mathrm{Mg}, \mathrm{Mn}, \mathrm{Na}, \mathrm{Zn}$ and $\mathrm{Ca}$ contents of the various cooking methods but the $\mathrm{K}$ content of the Uncooked African breadfruit (1766.66 \pm 57.73$)$ was significantly higher when compared to the other cooking methods Boiled (1333.33 \pm 208.16$)$, Fried (1533.33 \pm 152.75$)$, Pressure cooking $(1566.66 \pm 57.73)$ and Microwave cooking $(1133.33 \pm 57.73)$. Increase was in this order: Uncooked $>$ Pressure cooking $>$ Fried $>$ Boiled $>$ Microwave cooking.

There was a significant decrease in the $\beta$-carotene content of the Uncooked Melon seeds $(12462.13 \pm 39.11)$ when compared to the other cooking methods; the Boiled $(19223.61 \pm 4.00)$, Fried (19137.83 \pm 148.37$)$, Pressure cooking $(19131.74 \pm 6.08)$ and Microwave cooking $(19028.59 \pm 62.12)$. Decrease was in this order: Uncooked $<$ Microwave cooking $<$ Pressure cooking $<$ Fried $<$ Boiled. There was a significant increase in the $\mathrm{K}$ content of the uncooked melon seeds $(1633.33 \pm 152.75)$ when compared to Boiled (1266.66 \pm 57.73$)$, Pressure cooking (1200.00 \pm 100.00$)$ and Microwave cooking $(1333.33 \pm 57.73)$ but there was no significant difference in the Fried $(1533.33 \pm 115.47)$ when compared to the Uncooked $(1633.33 \pm 152.75)$. The increase was in this order: Un- 
cooked $>$ Microwave cooking > Boiled $>$ Pressure cooking. No significant difference was seen in the Ascorbic acid, $\mathrm{Cu}, \mathrm{Fe}, \mathrm{Mg}, \mathrm{Mn}$, $\mathrm{Na}, \mathrm{Zn}$ and $\mathrm{Ca}$ contents of the various cooking methods.

A significant decrease in the $\beta$-carotene content of the Uncooked Groundnut (13010.15 \pm 715.86$)$ was observed when compared to the other cooking methods; the Boiled (18266.59 \pm 5.60$)$, Fried (18759.79 \pm 16.13$)$, Pressure cooking $(18214.43 \pm 14.01)$ and $\mathrm{Mi}-$ crowave cooking $(18234.52 \pm 20.4)$. The decrease was in this order: Uncooked $<$ Pressure cooking $<$ Microwave cooking $<$ Boiled $<$ Fried. The increases and decreases of the various cooking methods in Ascorbic acid, $\mathrm{Cu}, \mathrm{Fe}, \mathrm{Mg}, \mathrm{Mn}, \mathrm{Na}, \mathrm{Zn}$ and $\mathrm{Ca}$ contents of groundnut were found to be not significant. However, there was a significant increase in the $\mathrm{K}$ content of the Uncooked groundnut $(1833.33 \pm 115.47)$ when compared to the Boiled (1333.33 \pm 115.47$)$, Pressure cooking $(1433.33 \pm 115.47)$ and $\mathrm{Mi}-$ crowave cooking $(1166.66 \pm 57.73)$. The increase was in this order: Uncooked $>$ Pressure cooking $>$ Boiled $>$ Microwave cooking. There was no significant difference when $\mathrm{K}$ content of the Fried $(1566.66 \pm 57.73)$ was compared to the Uncooked (1833.33 \pm 115.47$)$.

Table 1: Micronutrient Composition (Mg/100g Dry Weight) of African Bread Fruit (Treculia Africana) by Various Cooking Methods

\begin{tabular}{|c|c|c|c|c|c|}
\hline & Uncooked & Boiled & Fried & Pressure cooking & Microwave cooking \\
\hline B-carotene & $12278.94 \pm 32.22^{\mathrm{a}}$ & $18817.08 \pm 5.06^{\mathrm{b}}$ & $18923.11 \pm 4.60^{b}$ & $18355.83 \pm 96.43^{c}$ & $18265.33 \pm 17.34^{\mathrm{c}}$ \\
\hline Ascorbic acid & $70.39 \pm 0.10^{\mathrm{c}}$ & $57.88 \pm 0.51^{\mathrm{c}}$ & $56.18 \pm 0.07^{\mathrm{c}}$ & $57.97 \pm 0.61^{c}$ & $59.93 \pm 0.54^{c}$ \\
\hline $\mathrm{Cu}$ & $15.66 \pm 0.57^{c}$ & $13.66 \pm 0.57^{\mathrm{c}}$ & $14.33 \pm 0.57^{c}$ & $12.33 \pm 0.57^{c}$ & $12.00 \pm 1.00^{c}$ \\
\hline $\mathrm{K}$ & $1766.66 \pm 57.73^{\mathrm{a}}$ & $1333.33 \pm 208.16^{\mathrm{b}}$ & $1533.33 \pm 152.75^{\mathrm{c}}$ & $1566.66 \pm 57.73^{c}$ & $1133.33 \pm 57.73^{d}$ \\
\hline $\mathrm{Mg}$ & $773.33 \pm 11.54^{\mathrm{c}}$ & $726.66 \pm 5.77^{\mathrm{c}}$ & $736.66 \pm 5.77^{\mathrm{c}}$ & $713.33 \pm 5.77^{\mathrm{c}}$ & $723.33 \pm 5.77^{\mathrm{c}}$ \\
\hline $\mathrm{Mn}$ & $27.66 \pm 0.57^{c}$ & $23.66 \pm 0.57^{\mathrm{c}}$ & $22.66 \pm 0.57^{c}$ & $24.33 \pm 0.57^{c}$ & $24.66 \pm 0.57^{c}$ \\
\hline $\mathrm{Na}$ & $869.33 \pm 1.15^{\mathrm{c}}$ & $793.66 \pm 3.51^{\mathrm{c}}$ & $822.00 \pm 2.00^{c}$ & $781.33 \pm 2.5^{\mathrm{c}}$ & $779.33 \pm 2.08^{c}$ \\
\hline $\mathrm{Zn}$ & $37.33 \pm 1.15^{\mathrm{c}}$ & $33.66 \pm 1.15^{\mathrm{c}}$ & $31.66 \pm 1.52^{\mathrm{c}}$ & $31.00 \pm 1.73^{c}$ & $27.33 \pm 0.57^{c}$ \\
\hline $\mathrm{Ca}$ & $884.33 \pm 3.78^{c}$ & $835.66 \pm 5.68^{c}$ & $854.00 \pm 3.00^{c}$ & $847.66 \pm 5.50^{c}$ & $835.00 \pm 3.00^{\mathrm{c}}$ \\
\hline
\end{tabular}

Values are means of triplicate determinations \pm S.D. Means with same superscript letter(s) $(\mathrm{a}, \mathrm{b}, \mathrm{c})$ are not significantly different at $\mathrm{p} \leq 0.05$

Table 2: Micronutrient Composition (Mg/100g Dry Weight) of Melon Seeds (Citrullus Vulgaris) by Various Cooking Methods

\begin{tabular}{|c|c|c|c|c|c|}
\hline & Uncooked & Boiled & Fried & Pressure cooking & Microwave cooking \\
\hline B-carotene & $12462.13 \pm 39.11^{\mathrm{a}}$ & $19223.61 \pm 4.00^{\mathrm{b}}$ & $19137.83 \pm 148.37^{\text {bc }}$ & $19131.74 \pm 6.08^{\mathrm{bc}}$ & $19028.59 \pm 62.12^{\mathrm{c}}$ \\
\hline Ascorbic acid & $71.31 \pm 1.58^{c}$ & $57.90 \pm 0.52^{\mathrm{c}}$ & $55.62 \pm 0.50^{c}$ & $57.74 \pm 0.21^{\mathrm{c}}$ & $52.56 \pm 0.61^{\mathrm{c}}$ \\
\hline $\mathrm{Cu}$ & $18.66 \pm 0.57^{c}$ & $13.33 \pm 1.15^{\mathrm{c}}$ & $12.33 \pm 1.15^{\mathrm{c}}$ & $14.00 \pm 1.00^{c}$ & $13.00 \pm 1.00^{\mathrm{c}}$ \\
\hline $\mathrm{Fe}$ & $75.33 \pm 2.08^{c}$ & $63.00 \pm 1.73^{c}$ & $61.00 \pm 1.00^{c}$ & $65.33 \pm 1.52^{\mathrm{c}}$ & $59.00 \pm 1.73^{c}$ \\
\hline K & $1633.33 \pm 152.75^{a}$ & $1266.66 \pm 57.73^{b}$ & $1533.33 \pm 115.47^{\mathrm{a}}$ & $1200.00 \pm 100.00^{\mathrm{b}}$ & $1333.33 \pm 57.73^{\mathrm{b}}$ \\
\hline $\mathrm{Mg}$ & $766.66 \pm 11.54^{\mathrm{c}}$ & $733.33 \pm 11.54^{c}$ & $743.33 \pm 11.54^{c}$ & $733.33 \pm 11.54^{c}$ & $733.33 \pm 15.27^{c}$ \\
\hline $\mathrm{Mn}$ & $28.66 \pm 2.30^{c}$ & $25.33 \pm 1.52^{\mathrm{c}}$ & $27.66 \pm 0.57^{c}$ & $25.00 \pm 1.73^{c}$ & $26.33 \pm 1.15^{\mathrm{c}}$ \\
\hline $\mathrm{Na}$ & $885.66 \pm 5.85^{\mathrm{c}}$ & $784.66 \pm 3.21^{\mathrm{c}}$ & $818.66 \pm 8.50^{c}$ & $776.00 \pm 4.00^{c}$ & $783.66 \pm 6.35^{\mathrm{c}}$ \\
\hline $\mathrm{Zn}$ & $44.00 \pm 3.60^{c}$ & $36.66 \pm 1.52^{c}$ & $37.33 \pm 0.57^{c}$ & $34.00 \pm 2.00^{c}$ & $36.33 \pm 1.15^{\mathrm{c}}$ \\
\hline $\mathrm{Ca}$ & $887.33 \pm 3.51^{\mathrm{c}}$ & $842.66 \pm 3.05^{c}$ & $849.00 \pm 1.00^{c}$ & $839.00 \pm 2.64^{c}$ & $847.66 \pm 3.21^{c}$ \\
\hline
\end{tabular}

Values are means of triplicate determinations \pm S.D. Means with same superscript letter(s) $(a, b, c)$ are not significantly different at $\mathrm{p} \leq 0.05$.

Table 3: Micronutrient Composition (Mg/100g Dry Weight) of Groundnut (Arachis Hypogea) by Various Cooking Methods

\begin{tabular}{|c|c|c|c|c|c|}
\hline & Uncooked & Boiled & Fried & Pressure cooking & Microwave cooking \\
\hline B-carotene & $13010.15 \pm 715.86^{\mathrm{a}}$ & $18266.59 \pm 5.60^{\mathrm{b}}$ & $18759.79 \pm 16.13^{\mathrm{c}}$ & $18214.43 \pm 14.01^{\mathrm{b}}$ & $18234.52 \pm 20.43^{\mathrm{b}}$ \\
\hline Ascorbic acid & $74.25 \pm 1.85^{\mathrm{c}}$ & $57.53 \pm 1.14^{\mathrm{c}}$ & $56.78 \pm 0.50^{c}$ & $57.56 \pm 1.17^{\mathrm{c}}$ & $56.74 \pm 0.82^{\mathrm{c}}$ \\
\hline $\mathrm{Cu}$ & $17.00 \pm 1.00^{c}$ & $13.33 \pm 1.15^{\mathrm{c}}$ & $14.33 \pm 1.15^{\mathrm{c}}$ & $13.00 \pm 1.00^{c}$ & $11.66 \pm 0.57^{\mathrm{c}}$ \\
\hline $\mathrm{Fe}$ & $71.66 \pm 1.52^{\mathrm{c}}$ & $61.33 \pm 1.15^{\mathrm{c}}$ & $66.33 \pm 1.15^{\mathrm{c}}$ & $57.33 \pm 0.57^{\mathrm{c}}$ & $61.33 \pm 1.52^{\mathrm{c}}$ \\
\hline K & $1833.33 \pm 115.47^{\mathrm{a}}$ & $1333.33 \pm 115.47^{\mathrm{bc}}$ & $1566.66 \pm 57.73^{\mathrm{ab}}$ & $1433.33 \pm 115.47^{\mathrm{bc}}$ & $1166.66 \pm 57.73^{\mathrm{c}}$ \\
\hline $\mathrm{Mg}$ & $788.33 \pm 3.78^{c}$ & $720.00 \pm 10.00^{c}$ & $740.00 \pm 10.00^{c}$ & $713.33 \pm 5.77^{\mathrm{c}}$ & $733.33 \pm 5.77^{c}$ \\
\hline $\mathrm{Mn}$ & $30.66 \pm 1.15^{\mathrm{c}}$ & $22.66 \pm 0.57^{c}$ & $21.66 \pm 0.57^{c}$ & $23.66 \pm 0.57^{c}$ & $21.33 \pm 1.52^{\mathrm{c}}$ \\
\hline $\mathrm{Na}$ & $875.00 \pm 2.00^{c}$ & $793.00 \pm 1.00^{c}$ & $818.33 \pm 1.15^{\mathrm{c}}$ & $778.66 \pm 1.15^{\mathrm{c}}$ & $773.00 \pm 3.60^{c}$ \\
\hline $\mathrm{Zn}$ & $42.33 \pm 4.04^{\mathrm{c}}$ & $31.66 \pm 1.52^{\mathrm{c}}$ & $32.66 \pm 1.52^{\mathrm{c}}$ & $29.33 \pm 1.15^{\mathrm{c}}$ & $28.33 \pm 1.52^{\mathrm{c}}$ \\
\hline $\mathrm{Ca}$ & $874.00 \pm 3.60^{c}$ & $831.66 \pm 1.52^{c}$ & $851.33 \pm 1.15^{\mathrm{c}}$ & $846.00 \pm 2.64^{c}$ & $831.00 \pm 1.73^{c}$ \\
\hline
\end{tabular}

Values are means of triplicate determinations \pm S.D. Means with same superscript letter(s) (a, b, c) are not significantly different at $\mathrm{p} \leq 0.05$.

Table 4: Micronutrient Composition (Mg/100g Dry Weight) of African Oil Bean (Pentaclethra Macrophylla) by Various Cooking Methods

\begin{tabular}{|c|c|c|c|c|c|}
\hline & Uncooked & Boiled & Fried & Pressure cooking & Microwave cooking \\
\hline B-carotene & $10951.81 \pm 2.24^{\mathrm{a}}$ & $10823.49 \pm 1.17^{\mathrm{b}}$ & $10522.40 \pm 1.06^{\mathrm{c}}$ & $10831.07 \pm 3.07^{\mathrm{ab}}$ & $10509.16 \pm 7.99^{c}$ \\
\hline Ascorbic acid & $71.40 \pm 0.07^{\mathrm{c}}$ & $68.04 \pm 0.54^{c}$ & $52.50 \pm 0.67^{c}$ & $65.22 \pm 1.73^{c}$ & $60.81 \pm 0.48^{c}$ \\
\hline $\mathrm{Cu}$ & $19.00 \pm 1.73^{c}$ & $15.33 \pm 1.15^{\mathrm{c}}$ & $13.33 \pm 1.52^{\mathrm{c}}$ & $16.00 \pm 1.73^{c}$ & $15.33 \pm 0.57^{\mathrm{c}}$ \\
\hline $\mathrm{Fe}$ & $81.33 \pm 1.52^{\mathrm{c}}$ & $66.33 \pm 2.08^{c}$ & $58.33 \pm 5.03^{c}$ & $65.00 \pm 3.00^{c}$ & $60.66 \pm 0.57^{c}$ \\
\hline $\mathrm{K}$ & $2033.33 \pm 208.16^{\mathrm{a}}$ & $1200.00 \pm 0.00^{\mathrm{bc}}$ & $1133.33 \pm 57.73^{b}$ & $1266.66 \pm 115.47^{c}$ & $1266.66 \pm 57.73^{c}$ \\
\hline $\mathrm{Mg}$ & $826.66 \pm 11.54^{c}$ & $743.33 \pm 15.27^{\mathrm{c}}$ & $716.66 \pm 5.77^{c}$ & $753.33 \pm 15.27^{\mathrm{c}}$ & $730.00 \pm 20.00^{c}$ \\
\hline $\mathrm{Mn}$ & $43.33 \pm 3.51^{\mathrm{c}}$ & $35.33 \pm 3.05^{\mathrm{c}}$ & $29.00 \pm 2.00^{c}$ & $36.00 \pm 1.73^{\mathrm{c}}$ & $31.33 \pm 2.30^{c}$ \\
\hline $\mathrm{Na}$ & $917.00 \pm 8.88^{\mathrm{a}}$ & $767.66 \pm 36.11^{\mathrm{b}}$ & $742.66 \pm 4.04^{b}$ & $774.00 \pm 11.78^{b}$ & $721.66 \pm 2.08^{b}$ \\
\hline $\mathrm{Zn}$ & $53.33 \pm 3.51^{\mathrm{c}}$ & $45.33 \pm 3.05^{\mathrm{c}}$ & $43.33 \pm 0.57^{\mathrm{c}}$ & $42.66 \pm 2.08^{c}$ & $39.33 \pm 3.05^{\mathrm{c}}$ \\
\hline $\mathrm{Ca}$ & $808.66 \pm 7.57^{\mathrm{a}}$ & $628.66 \pm 4.16^{\mathrm{b}}$ & $638.00 \pm 2.00^{\mathrm{b}}$ & $612.00 \pm 2.64^{\mathrm{b}}$ & $625.33 \pm 10.26^{\mathrm{b}}$ \\
\hline
\end{tabular}

Values are means of triplicate determinations \pm S.D. Means with same superscript letter(s) (a, b, c) are not significantly different at $\mathrm{p} \leq 0.05$.

B-carotene content of the Uncooked African oil bean $(10951.81 \pm 2.24)$ revealed a significant increase when compared to

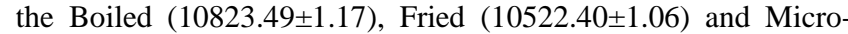
wave cooking $(10509.16 \pm 7.99)$. There was no significant difference in the $\beta$-carotene content of the Pressure cooking $(10831.07 \pm 3.07)$ when compared to the Uncooked (10951.81 \pm 2.24$)$. Increase was in this order: Uncooked $>$ Boiled $>$ Fried $>$ Microwave cooking. The contents of
Ascorbic acid, $\mathrm{Cu}, \mathrm{Fe}, \mathrm{Mg}, \mathrm{Mn}$ and $\mathrm{Zn}$ revealed no significant difference of the various cooking methods. However, there was a significant increase in the $\mathrm{K}$ content of the Uncooked (2033.33 \pm 208.16$)$ when compared to the Boiled (1200.00 \pm 0.00$)$, Fried (1133.33 \pm 57.73$)$, Pressure cooking (1266.66 \pm 115.47$)$ and Microwave cooking $(1266.66 \pm 57.73)$. This increase was in this order: Uncooked $>$ Pressure cooking $>$ Microwave cooking $>$ Boiled $>$ Fried. There was also a significant increase in the $\mathrm{Na}$ 
content of the Uncooked (917.00 \pm 8.88$)$ when compared to the Boiled (767.66 \pm 36.11$)$, Fried (742.66 \pm 4.04$)$, Pressure cooking (774.00 \pm 11.78$)$ and Microwave cooking $(721.66 \pm 2.08)$. The increase was in this order: Uncooked $>$ Pressure cooking $>$ Boiled $>$ Microwave cooking $>$ Fried. Ca content of the Uncooked African oil bean (808.66 \pm 7.57$)$ also showed a significant increase when compared to the Boiled $(628.66 \pm 4.16)$, Fried (638.00 \pm 2.00$)$, Pressure cooking $(612.00 \pm 2.64)$ and Microwave cooking $(625.33 \pm 10.26)$. The increase was in this order: Uncooked $>$ Fried $>$ Boiled $>$ Microwave cooking $>$ Pressure cooking. Microwaving is an easy, convenient and safe method of cooking. Short cooking times and reduced exposure to heat preserve the nutrients in microwaved food (Cross and Fung, 1982). This study revealed a less mineral content retention as well as $\beta$ - carotene and Ascorbic acid content retention of the selected legumes by $\mathrm{Mi}-$ crowave cooking when compared to the other cooking methods. Frying entails cooking for a short time without water which prevents loss of vitamins and the addition of fat improves the absorption of plant compounds and antioxidants. It is a popular way of preparing food because the skin or coating maintains a seal, which ensures that the inside remains moist and cooks evenly (Veda $e t$ al., 2006). This present study revealed lesser micronutrient retention in some of the legumes when compared to the other cooking methods. A study found that absorption of $\beta$-carotene was 6.5 times greater in fried carrots than in raw (Ghavami et al., 2012). In another study, blood lycophene levels increased $80 \%$ more when people consumed tomatoes fried in olive oil rather than without (Fielding et al., 2005). On the other hand, frying has been shown to significantly reduce the amount of Ascorbic acid in broccoli and red cabbage (Chuli, 2013).

There was a significant increase in the $\beta$-carotene content of Cashew nut of the uncooked sample $(17240.62 \pm 3.04)$ when compared to the Boiled (15374.85 \pm 7.07$)$, Fried $(16315.59 \pm 65.03)$, Pressure cooking (15631.28 \pm 138.80$)$ and Microwave cooking (15042.30 \pm 27.07$)$. Increase was in this order: Uncooked $>$ Fried $>$ Pressure cooking $>$ Boiled $>$ Microwave cooking. The $\mathrm{K}$ content revealed a significant increase of the Uncooked $(1500.00 \pm 200.00)$ when compared to the Boiled (1233.33 \pm 152.75$)$, Fried $(1200.00 \pm 100.00)$, and Pressure cooking (1166.66 \pm 115.47$)$. Increase was in this order: Uncooked $>$ Boiled $>$ Fried $>$ Pressure cooking. There was no significant difference in the Microwave cooking $(1366.66 \pm 57.73)$ when compared to the Uncooked (1500.00 \pm 200.00$)$. Ascorbic acid, $\mathrm{Cu}, \mathrm{Fe}$, $\mathrm{Mg}, \mathrm{Mn}, \mathrm{Na}, \mathrm{Zn}$ and $\mathrm{Ca}$ showed no significant difference in their contents of the various cooking methods.

Table 5: Micronutrient Composition (Mg/100g Dry Weight) of Cashewnut (Anacardum Occidentalia) by Various Cooking Methods

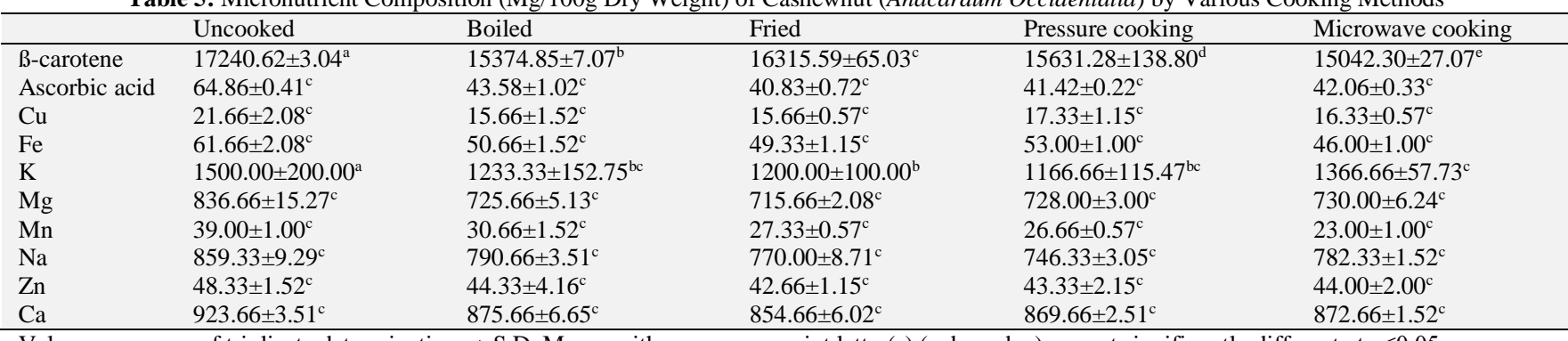

Values are means of triplicate determinations \pm S.D. Means with same superscript letter(s) $(\mathrm{a}, \mathrm{b}, \mathrm{c}, \mathrm{d}, \mathrm{e})$ are not significantly different at $\mathrm{p}<0.05$.

Table 6: Micronutrient Composition (Mg/100g Dry Weight) of Coconut (Cocos Nucifera) by Various Cooking Methods

\begin{tabular}{|c|c|c|c|c|c|}
\hline & Uncooked & Boiled & Fried & Pressure cooking & Microwave cooking \\
\hline ß-carotene & $13456.18 \pm 8.12^{\mathrm{a}}$ & $11841.21 \pm 4.50^{b}$ & $11626.29 \pm 5.17^{\mathrm{cd}}$ & $11781.53 \pm 5.48^{\mathrm{bc}}$ & $11537.13 \pm 4.34^{\mathrm{d}}$ \\
\hline Ascorbic acid & $64.66 \pm 1.20^{c}$ & $44.74 \pm 6.24^{c}$ & $57.01 \pm 1.06^{\mathrm{c}}$ & $53.66 \pm 0.44^{\mathrm{c}}$ & $53.42 \pm 1.03^{\mathrm{c}}$ \\
\hline $\mathrm{Cu}$ & $16.00 \pm 2.00^{\mathrm{c}}$ & $12.00 \pm 1.00^{\mathrm{c}}$ & $13.00 \pm 1.73^{c}$ & $14.00 \pm 2.00^{c}$ & $13.33 \pm 2.00^{\mathrm{c}}$ \\
\hline $\mathrm{K}$ & $1633.33 \pm 305.50^{\mathrm{a}}$ & $1233.33 \pm 152.75^{b}$ & $1333.33 \pm 115.47^{b}$ & $1366.66 \pm 115.47^{b}$ & $1300.00 \pm 3.20^{\mathrm{b}}$ \\
\hline $\mathrm{Mg}$ & $839.00 \pm 8.54^{\mathrm{a}}$ & $639.33 \pm 11.23^{\mathrm{b}}$ & $650.66 \pm 2.08^{\mathrm{ab}}$ & $642.33 \pm 4.04^{\mathrm{ab}}$ & $772.66 \pm 3.51^{\mathrm{ab}}$ \\
\hline $\mathrm{Mn}$ & $38.66 \pm 1.52^{c}$ & $26.66 \pm 2.51^{c}$ & $21.00 \pm 1.00^{c}$ & $36.33 \pm 2.08^{c}$ & $34.66 \pm 1.52^{\mathrm{c}}$ \\
\hline $\mathrm{Na}$ & $890.66 \pm 8.14^{a}$ & $717.00 \pm 5.29^{\mathrm{ab}}$ & $645.66 \pm 4.50^{b}$ & $709.00 \pm 5.56^{\mathrm{ab}}$ & $633.00 \pm 3.60^{\mathrm{b}}$ \\
\hline $\mathrm{Zn}$ & $36.66 \pm 1.52^{c}$ & $30.00 \pm 1.00^{c}$ & $32.33 \pm 1.15^{\mathrm{c}}$ & $26.33 \pm 2.08^{c}$ & $31.66 \pm 1.52^{c}$ \\
\hline $\mathrm{Ca}$ & $647.33 \pm 2.51^{\mathrm{c}}$ & $586.00 \pm 2.00^{c}$ & $572.00 \pm 2.00^{c}$ & $544.33 \pm 2.51^{\mathrm{c}}$ & $556.66 \pm 4.04^{\mathrm{c}}$ \\
\hline
\end{tabular}

Values are means of triplicate determinations \pm S.D. Means with same superscript letter(s) $(\mathrm{a}, \mathrm{b}, \mathrm{c}, \mathrm{d})$ are not significantly different at $\mathrm{p} \leq 0.05$.

There was a significant increase in the $\beta$-carotene content of the uncooked coconut $(13456.18 \pm 8.12)$ when compared to the Boiled (11841.21 \pm 4.50$)$, Fried (11626.29 \pm 5.17$)$, Pressure cooking

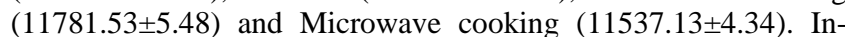
crease was in this order: Uncooked $>$ Boiled $>$ Pressure cooking $>$ Fried $>$ Microwave cooking. The $\mathrm{K}$ content of the Uncooked $(1633.33 \pm 305.50)$ was significantly higher than the Boiled (1233.33 \pm 152.75$)$, Fried (1333.33 \pm 115.47$)$, Pressure cooking $(1366.66 \pm 115.47)$ and Microwave cooking (1300.00 \pm 3.20$)$. Increase was in this order: Uncooked $>$ Pressure cooking $>$ Fried $>$ Microwave cooking $>$ Boiled. Mg content of the Uncooked $(839.00 \pm 8.54)$ was significantly increased when compared to the Boiled $(639.33 \pm 11.23)$ but there was no significant difference when the other cooking methods were compared to the Uncooked. Na content of the Uncooked Coconut (890.66 \pm 8.14$)$ was significantly increased when compared to the Fried $(645.66 \pm 4.50)$ and Microwave cooking (633.00 \pm 3.60$)$. Increase was in this order: Uncooked $>$ Fried $>$ Microwave cooking. However, there was no significant difference when the Boiled (717.00 \pm 5.29$)$ and Pressure cooking $(709.00 \pm 5.56)$ were compared against the Uncooked (890.66 \pm 8.14$)$. There was no significant difference in the Ascorbic acid, $\mathrm{Cu}, \mathrm{Fe}, \mathrm{Mn}, \mathrm{Zn}$ and $\mathrm{Ca}$ contents of the various cooking methods.

Cooking food improves digestion and increases absorption of many nutrients (Carmody and Wrangham, 2009). For example, protein in cooked eggs is $180 \%$ more digestible than in raw eggs (Evenepoel et al., 1998). However, several key nutrients are reduced with some cooking methods. Cooking increases dietary fibre content but also induces losses of vitamins and minerals of legumes (Walker and Kohhar, 1982). Heat processing when done under controlled time and temperature usually improves the protein quality of grain legumes (Bressani, 1985). Jasraj and Kiran (2010) reported a reduction $(p \leq 0.05)$ in $\beta$-carotene content after cooking. This loss increased with increase in cooking time. Similar results were reported by Nagra and Khan, (1988). Ascorbic acid content of a study by Jasraj and Kiran (2010), reduced during pressure cooking and boiling. Higher losses during boiling may be due to leaching of ascorbic acid in water as both cooking time and amount of water used was more in boiling as compared to pressure cooking. Moftugil (1986), also reported greater losses of ascorbic acid during boiling than microwaving, losses being $14.2 \%$ and $9.3 \%$ respectively. The Boiling method in most of the selected legumes according to this present study showed higher micronu- 
trient retention when compared to other cooking methods. Boiling reduces Ascorbic acid more than any other cooking method. Prolonged boiling had detrimental effect on this vitamin (Yuan et al., 2009). Unlike in vegetables and nuts, boiling fish has been shown to preserve omega-3 fatty acid content significantly more than frying or microwaving (Nimish et al., 2010). There was less micronutrient retention by pressure cooking of the selected legumes according to this present study. Pressure cooking can reduce heatsensitive nutrients (e.g., vitamin $\mathrm{C}$, folate) and bioactive phytonutrients, such as betacarotene and omega- 3 fatty acids, that are beneficial for human health. In many legumes, heat-sensitive vitamins and phytonutrients are vulnerable to deterioration. The net result of pressure cooking is a positive nutritional gain-from the increased digestibility of macronutrients and the increased bioavailability of the essential minerals (Jasraj and Kiran, 2010).

\section{Conclusion}

As revealed by this study, Boiling, Frying, Pressure cooking and Microwave cooking affected the micronutrient composition of the selected legumes. The Boiling method of cooking showed the most retention of the micronutrients whereas the Fried and Microwave cooking methods showed more losses in micronutrient content. Although boiling could lead to nutrient losses as revealed by some studies, there was maximum micronutrient retention of the legumes by the Boiling method as shown by this study.

\section{References}

[1] Aremu, M.O., Olonisakin, A., Otene, I.W. and Atolaiye, B.O (2005a). Mineral content of some agricultural products grown in the middle belt of Nigeria. Oriental Journal of Chemistry, 21(3), 419 425.

[2] Bressani, R. (1985). Nutritive value of cowpea. In: Singh, S.R. and Rachie, K.O, editors. Cowpea research, production and utilization. New York, Wiley, pp. 353-360.

[3] Carmody, R.N. and Wrangham, R.W. (2009). Cooking and the human commitment to a high-quality diet. Cold Spring Harbor Symposia on Quantitative Biology, 4, 427-434.

[4] Chuli, Z. (2013). Effects of different cooking methods on the vitamin C content of selected vegetables. Nutrition \& Food Science, 43(5), 438-443. https://doi.org/10.1108/NFS-11-2012-0123.

[5] Cross, G.A. and Fung, D.Y. (1982). The effect of microwaves on nutrient value of foods. Critical Reviews in Food Science and $\mathrm{Nu}$ trition, 16(4), 355-381.

[6] Evenepoel, P., Geypens, B., Luypaerts, A., Hiele, M., Ghoos, Y. and Rutgeerts, P. (1998). Digestibility of cooked and raw egg protein in humans as assessed by stable isotope techniques. Journal of Nutrition, 128(100, 1716-1722.

[7] Fielding, J.M., Rowley, K.G., Cooper, P. and O' Dea, K. (2005) Increases in plasma lycophene concentration after consumption of tomatoes cooked with olive oil. Asia Pacific Journal of Clinical Nutrition, 14(2), 131-136.

[8] Fleck, H. (1976). Introduction to Nutrition, 3rd edition, Macmillan New York, pp. 207 - 219.

[9] Ghavami, A., Coward, W.A. and Bluck, L.J. (2012). The effect of food preparation on the bioavailability of carotenoids from carrots using intrinsic labelling. British Journal of Nutrition, 107(9), 13501366. https://doi.org/10.1017/S000711451100451X.

[10] Harris, R.S. (1988). General discussion on the stability of nutrients In: Nutritional Evaluation of Food Processing. Edited by Karmas, E. and Harris, R.S. New York, Van Nostrand Reinhold Co, pp. 3-6. https://doi.org/10.1007/978-94-011-7030-7_1.

[11] Hegsted, D.M., Chichester, C.O., Darby, W. J., Mcnutt, K.W., Stalvey, R.M., and Stotz, E.H. (1976). In: Present knowledge in nutrition (nutrition reviews'), fourth edition. The Nutrition Foundation Inc. New York, Washington.

[12] Hendricks, D.G. (2002). Mineral analysis by traditional methods In: Introduction to the Chemical Analysis of Food. CBS, New Delhi, India, pp. 123 - 130.

[13] IVACG (1992).Reprints of selected methods for analyses of vitamin A and carotenoids in nutrition surveys.The nutrition Foundation, Washington, D.C. 16-18.

[14] Jasraj, K.D. and Kiran, B. (2010). Effect of household cooking methods on nutritional and anti-nutritional factors in green cowpea
(Vigna unguiculata) pods. Journal of Food Science and Technology, 47(5), 579-581. https://doi.org/10.1007/s13197-010-0112-3.

[15] Jones, E. and Hughes, R.E. (1983). Foliar ascorbic acid in some angiosperms. Phytochemistry 22(11):2493-2499.

[16] Kala, A. and Prakash. J., (2001). Chemical composition and sensory attributes of differently cooked starchy vegetables. Indian Journal of Nutrition and Dietetics, 38, 338-349.

[17] Lee, K. and Clydesdale, F.M. (1981). Effect of thermal processing on endogenous and added iron in canned spinach. Journal of Food Science, 46, 1064-1067.

[18] Moftugil, N. (1986). Effect of different types of blanching on the colour and the ascorbic acid and chlorophyll contents of green beans. Journal of Food processing and Preservation, 10, 69-76. https://doi.org/10.1111/j.1745-4549.1986.tb00006.x.

[19] Nagra, S.A. and Khan, S. (1988). Vitamin A (B-carotene) losses in Pakistani cooking. Journal of Food and Agricultural Sciences, 46, 249-251. https://doi.org/10.1002/jsfa.2740460213.

[20] Nimish, M.S., Jeya, R.S., Jeyasekaran, G. and Sukumar, D. (2010). Effect of different types of heat processing on chemical changes in tuna. Journal of Food Science and Technology, 47(2), 174-181. https://doi.org/10.1007/s13197-010-0024-2.

[21] Nnorom, I.C., Ewuzie, U., Ogbuagu, F., Okereke, M., Agwu, P. and Enyinnaya, I.P. (2015). Mineral contents of Ukwa, African Breadfruit (Treculia africana), from South-Eastern Nigeria: Effects of Methods of Preparation. International Journal of Plant and Soil Science, 4(3), 230-240. https://doi.org/10.9734/IJPSS/2015/12603.

[22] Pike, R.I. and Brown, M.L. (1967). Nutrition; An Inegrated Approach. Wiley, New York, USA, pp. $92-93$

[23] Shils, M. E. (1973). Magnesium. In: Introduction to Nutrition, H. Fleck (ed) (1976). 3rd edition, Macmillan New York, pp. 255.

[24] Somogyi, J.C. (1990). Influence of food preparation on nutritional quality: introductory remarks. Journal of Nutritional Science and Vitaminology, 36(suppll), SI-S6. https://doi.org/10.3177/jnsv.36.4SupplementI_S1.

[25] Tapadia, S. B. (1995). Vitamin C contents of processed vegetables. Journal of Food Science Technology, 32, 513-515.

[26] USEPA. (1987). Nonpoint source guidance. U.S.Environmental Protection Agency, Office of Water and Office of Water Regulations and Standards, Washington, DC.

[27] Veda, S., Kamath, A., Platel, K., Begum, K. and Srinivasan, K. (2006). Determination of beta-carotene in vegetables by in vitro methods. Molecular Nutrition and Food Research, 50(11), 1047 1052. https://doi.org/10.1002/mnfr.200600076.

[28] Vyas, D. and Changra, R.K. (1984). Iron Nutrition in Infancy and Childhood. Discovery and Innovation, 11, 75-81.

[29] Walker, A.F and Kohhar, N. (1982). Effect of processing including domestic cooking on nutritional quality of legumes. Proceedings of the Nutrition Society of India, 41, 41-50.

[30] Yuan, G.F., Sun, B., Yuan, J. and Wang, Q.M. (2009). Effects of different cooking methods on health-promoting compounds of broccoli. Journal of Zhejiang University Science B., 10(8), 580588. https://doi.org/10.1631/jzus.B0920051. 